\title{
Front Matter: Volume 9692
}

, "Front Matter: Volume 9692," Proc. SPIE 9692, Lasers in Dentistry XXII, 969201 (20 April 2016); doi: 10.1117/12.2231325

SPIE. Event: SPIE BiOS, 2016, San Francisco, California, United States 


\section{PROGRESS IN BIOMEDICAL OPTICS AND IMAGING}

\section{Lasers in Dentistry XXII}

Peter Rechmann

Daniel Fried

Editors

14 February 2016

San Francisco, California, United States

Sponsored and Published by

SPIE 
The papers in this volume were part of the technical conference cited on the cover and title page. Papers were selected and subject to review by the editors and conference program committee. Some conference presentations may not be available for publication. Additional papers and presentation recordings may be available online in the SPIE Digital Library at SPIEDigitallibrary.org.

The papers reflect the work and thoughts of the authors and are published herein as submitted. The publisher is not responsible for the validity of the information or for any outcomes resulting from reliance thereon.

Please use the following format to cite material from this book:

Author(s), "Title of Paper," in Lasers in Dentistry XXII, edited by Peter Rechmann, Daniel Fried, Proceedings of SPIE Vol. 9692 (SPIE, Bellingham, WA, 2016) Six-digit Article CID Number.

ISSN: 1605-7422

ISSN: $2410-9045$ (electronic)

ISBN: 9781628419269

Published by

SPIE

P.O. Box 10, Bellingham, Washington 98227-0010 USA

Telephone +1 3606763290 (Pacific Time) · Fax +1 3606471445

SPIE.org

Copyright (C) 2016, Society of Photo-Optical Instrumentation Engineers.

Copying of material in this book for internal or personal use, or for the internal or personal use of specific clients, beyond the fair use provisions granted by the U.S. Copyright Law is authorized by SPIE subject to payment of copying fees. The Transactional Reporting Service base fee for this volume is $\$ 18.00$ per article (or portion thereof), which should be paid directly to the Copyright Clearance Center (CCC), 222 Rosewood Drive, Danvers, MA 01923. Payment may also be made electronically through CCC Online at copyright.com. Other copying for republication, resale, advertising or promotion, or any form of systematic or multiple reproduction of any material in this book is prohibited except with permission in writing from the publisher. The CCC fee code is $1605-7422 / 16 / \$ 18.00$.

Printed in the United States of America.

Publication of record for individual papers is online in the SPIE Digital Library.

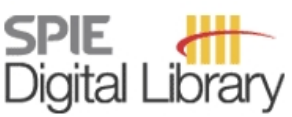

SPIEDigitallibrary.org

Paper Numbering: Proceedings of SPIE follow an e-First publication model, with papers published first online and then in print. Papers are published as they are submitted and meet publication criteria. A unique citation identifier (CID) number is assigned to each article at the time of the first publication. Utilization of CIDs allows articles to be fully citable as soon as they are published online, and connects the same identifier to all online, print, and electronic versions of the publication. SPIE uses a six-digit CID article numbering system in which:

- The first four digits correspond to the SPIE volume number.

- The last two digits indicate publication order within the volume using a Base 36 numbering

system employing both numerals and letters. These two-number sets start with 00, 01, 02, 03, 04, $05,06,07,08,09,0 A, 0 B \ldots 0 Z$, followed by 10-1Z, 20-2Z, etc.

The CID Number appears on each page of the manuscript. The complete citation is used on the first page, and an abbreviated version on subsequent pages. the six-digit CID number. 


\title{
Contents
}

\author{
$\checkmark \quad$ Authors \\ vii Conference Committee
}

\section{SESSION 1 LASERS AND ENDODONTICS, NANOPARTICLE DENTIN CONDITIONING}

969203 Digital moiré interferometric analysis on the effect of nanoparticle conditioning on the mechanical deformation in dentin [9692-3]

969204 Comparing irradiation parameters on disinfecting enterrecoccus faecalis in root canal disinfection [9692-1]

\section{SESSION $2 \quad \mathrm{CO}_{2}$ LASERS IN ABLATION AND CARIES PREVENTION, ER:YAG FOR DEBONDING}

969205 Microsecond enamel ablation with $10.6 \mu \mathrm{m} \mathrm{CO} 2$ laser radiation [9692-4]

969206 A new sealed RF-excited $\mathrm{CO}_{2}$ laser for enamel ablation operating at $9.4 \mu \mathrm{m}$ with a pulse

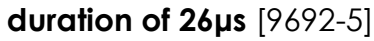

969208 Er:YAG laser metal and ceramic bracket debonding [9692-7]

\section{SESSION $3 \quad$ IMAGING OF DENTAL HARD TISSUES}

969209 A pilot study on the detection of early proximal and occlusal dental caries using longwave infrared thermophotonic imaging [9692-8]

$96920 \mathrm{~A}$ A system for simultaneous near-infrared reflectance and transillumination imaging of occlusal carious lesions [9692-9]

$9692 \mathrm{OB}$ Assessment of remineralized dentin lesions with thermal and near-infrared reflectance imaging [9692-10]

\section{SESSION 4 LASERS IN ORAL SURGERY}

9692 OE Blue diode laser: a new approach in oral surgery? [9692-13]

POSTER SESSION

$96920 \mathrm{~J}$ Evaluation of Vickers hardness of bulk-fill composites cured by different light sources [9692-18]

9692 OK Hard-tissue drilling by short-pulse $\mathrm{CO}_{2}$ laser with controllable pulse-tail energy [9692-19] 
$9692 \mathrm{OL}$ Diode $\lambda 830 \mathrm{~nm}$ laser associated with hydroxyapatite and biological membranes: bone repair in rats [9692-20]

9692 OM Structural changes in the irradiated dentin with Nd:YAG and Er:YAG lasers for cervical hypersensitivity treatment and their influence on the microtensile resistance in resin-dentin interface [9692-21]

$96920 \mathrm{~N}$ Evaluation of microshear bond strength of resin composites to enamel of dental adhesive systems associated with Er,Cr:YSGG laser [9692-22]

9692 OP Optical coherence tomography investigations of ceramic lumineers [9692-24]

$96920 Q \quad$ Monitoring the gingival regeneration after aesthetic surgery with optical coherence tomography [9692-25]

9692 OR A comparative study of shear bond strength of orthodontic bracket after acid-etched and Er:YAG treatment on enamel surface [9692-26]

9692 OS Selective removal of dental composite with a diode-pumped Er:YAG laser [9692-27]

9692 OT Enhancement of OCT images with vinyl polysiloxane (VPS) [9692-28]

9692 OU Selective removal of esthetic composite restorations with spectral guided laser ablation [9692-29]

$96920 \mathrm{~V}$ Assessment of simulated lesions on primary teeth with near-infrared imaging [9692-30]

9692 OW Evaluation of enamel surface modification using PS-OCT after laser treatment to increase resistance to demineralization [9692-31]

$96920 X$ Influence of stains on lesion contrast in the pits and fissures of tooth occlusal surfaces from 800-1600-nm [9692-32] 


\section{Authors}

Numbers in the index correspond to the last two digits of the six-digit citation identifier (CID) article numbering system used in Proceedings of SPIE. The first four digits reflect the volume number. Base 36 numbering is employed for the last two digits and indicates the order of articles within the volume. Numbers start with 00, 01, 02, 03, 04, 05, 06, 07, 08, 09, 0A, 0B...0Z, followed by 10-1Z, 20-2Z, etc.

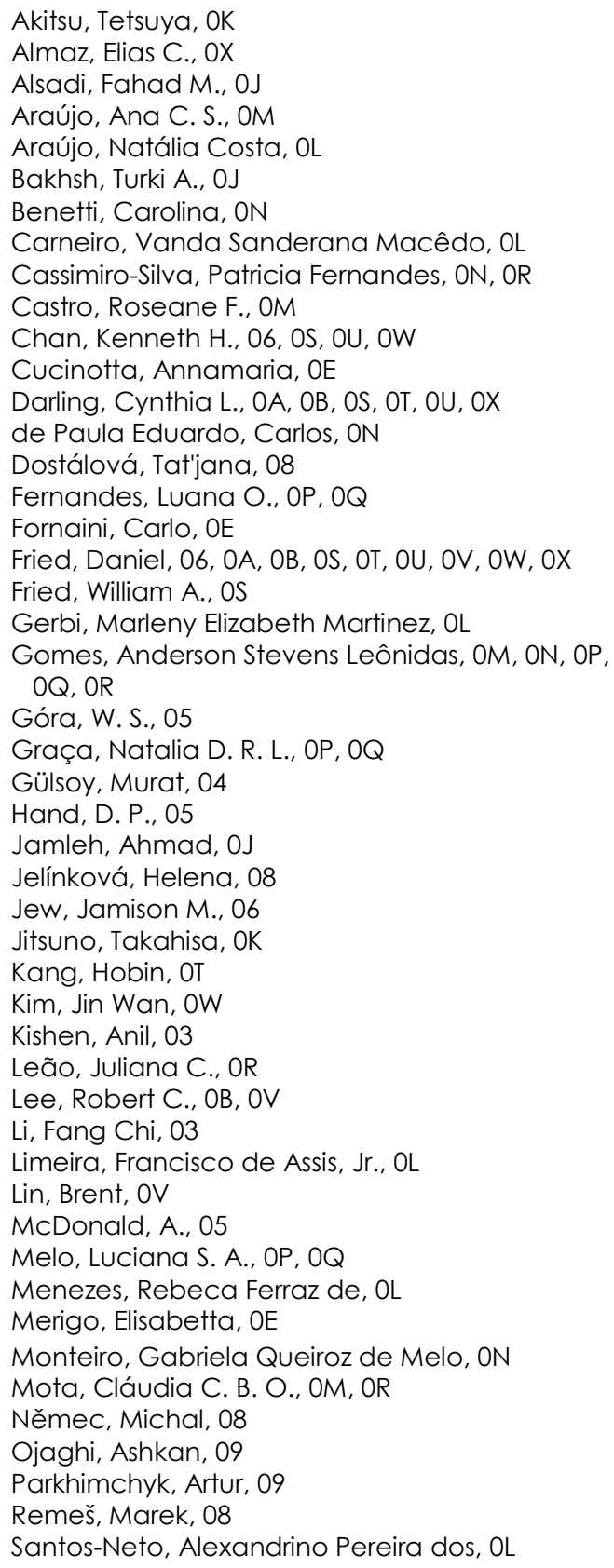

\author{
Sarp, Ayşe Sena, 04 \\ Sasaki, Tatsufumi, OK \\ Selleri, Stefano, OE \\ Sena, Tatiane V. N. S., OM \\ Shephard, J. D., 05 \\ Silva, Claudio H. V., OP, $O Q$ \\ Simon, Jacob C., OA, OV, OX \\ Staninec, Michal, OU \\ Šulc, Jan, 08 \\ Tabatabaei, Nima, 09 \\ Tam, Wilson, OV \\ Tsuji, Grant H., OU \\ Uno, Kazuyuki, OK \\ Vyhlídal, David, 08 \\ Yagmoor, Mohammed A., OJ \\ Yamamoto, Takuya, OK \\ Yi, Ivana, OU \\ Zezell, Denise Maria, ON
}


Proc. of SPIE Vol. $9692969201-6$

Downloaded From: https://www.spiedigitallibrary.org/conference-proceedings-of-spie on 26 Apr 2023 Terms of Use: https://www.spiedigitallibrary.org/terms-of-use 


\title{
Conference Committee
}

\author{
Symposium Chairs
}

James G. Fujimoto, Massachusetts Institute of Technology

(United States)

R. Rox Anderson, Wellman Center for Photomedicine, Massachusetts General Hospital (United States) and Harvard School of Medicine (United States)

Program Track Chair

Brian Jet-Fei Wong, Beckman Laser Institute and Medical Clinic (United States)

Conference Chairs

Peter Rechmann, University of California, San Francisco (United States)

Daniel Fried, University of California, San Francisco (United States)

Conference Program Committee

Gregory B. Altshuler, Palomar Medical Technologies, Inc. (United States)

Tatjána Dostálová M.D., Charles University in Prague (Czech Republic)

Thomas Ertl, Universität Stuttgart (Germany)

David M. Harris, Bio-Medical Consultants, Inc. (United States)

Jörg Meister, Universitätsklinikum Bonn (Germany)

Eric J. Seibel, University of Washington (United States)

\section{Session Chairs}

1 Lasers and Endodontics, Nanoparticle Dentin Conditioning

Peter Rechmann, University of California, San Francisco

(United States)

$2 \mathrm{CO}_{2}$ Lasers in Ablation and Caries Prevention, Er:YAG for Debonding Daniel Fried, University of California, San Francisco (United States)

3 Imaging of Dental Hard Tissues

Peter Rechmann, University of California, San Francisco (United States)

4 Lasers in Oral Surgery

Daniel Fried, University of California, San Francisco (United States) 
Proc. of SPIE Vol. $9692969201-8$

Downloaded From: https://www.spiedigitallibrary.org/conference-proceedings-of-spie on 26 Apr 2023 Terms of Use: https://www.spiedigitallibrary.org/terms-of-use 